\title{
RAPID STIMULATION OF SODIUM INTAKE COMBINING ALDOSTERONE INTO THE 4TH VENTRICLE AND THE BLOCKADE OF THE LATERAL PARABRACHIAL NUCLEUS
}

\author{
S. GASPARINI, M. R. MELO, G. F. LEITE, \\ P. A. NASCIMENTO, G. M. F. ANDRADE-FRANZÉ, \\ J. V. MENANI ${ }^{\dagger}$ AND E. COLOMBARI ${ }^{* \dagger}$ \\ Department of Physiology and Pathology, School of Dentistry \\ of Araraquara, São Paulo State University, UNESP, Araraquara, \\ $S P$, Brazil
}

\begin{abstract}
Chronic infusion of aldosterone into the 4th ventricle (4th $V$ ) induces robust daily sodium intake, whereas acute injection of aldosterone into the 4 th $V$ produces no sodium intake. The inhibitory mechanism of the lateral parabrachial nucleus (LPBN) restrains sodium intake induced by different natriorexigenic stimuli and might affect the acute response to aldosterone into the 4th $\mathrm{V}$. In the present study, $1.8 \% \mathrm{NaCl}$ and water intake was tested in rats treated with acute injections of aldosterone into the 4th $\mathrm{V}$ combined with the blockade of the inhibitory mechanisms with injections of moxonidine ( $\alpha_{2}$ adrenergic/imidazoline agonist) or methysergide (a serotonergic antagonist) into the LPBN. Male Holtzman rats with stainless steel cannulas implanted in the 4th V and bilaterally in the LPBN were used. Aldosterone ( 250 or $500 \mathrm{ng}$ ) into the 4th $\mathrm{V}$ combined with vehicle into the LPBN induced no $1.8 \%$ NaClintake compared to control (1.5 \pm 1.1 and $1.1 \pm 0.4$, respectively, vs. vehicle into 4th $V: 1.0$ $\pm 0.5 \mathrm{ml} / 2 \mathrm{~h}$ ). However, aldosterone (250 or $500 \mathrm{ng}$ ) into the 4th $\mathrm{V}$ combined with moxonidine $(0.5 \mathrm{nmol})$ into the LPBN induced strong ingestion of $1.8 \% \mathrm{NaCl}(12.7 \pm 4.6$ and $17.6 \pm 3.7 \mathrm{ml} / 2 \mathrm{~h}$, respectively). Aldosterone $(250 \mathrm{ng})$ into the 4th $\mathrm{V}$ combined with methysergide $(4 \mu \mathrm{g})$ into the LPBN also induced $1.8 \% \mathrm{NaCl}$ intake $(17.6 \pm 5.4 \mathrm{ml} / 2 \mathrm{~h})$. These data suggest that the inhibitory mechanisms of the LPBN counteract the facilitation of sodium intake produced by aldosterone injected into the 4th, restraining sodium intake in this condition. (c) 2017 IBRO. Published by Elsevier Ltd. All rights reserved.
\end{abstract}

Key words: sodium appetite, mineralocorticoids, hindbrain, HSD2 neurons.

\footnotetext{
"Corresponding author. Address: Department of Physiology and Pathology, School of Dentistry, Sao Paulo State University, UNESP, Rua Humaitá, 1680, 14801-903 Araraquara, SP, Brazil. Fax: +5516-33016488.

E-mail address: eduardo.colombari@foar.unesp.br (E. Colombari).

JVM and EC are co-senior authors.

Abbreviations: ANG II, angiotensin II; CeA, central nucleus of amygdala; DOCA, deoxycorticosterone acetate; GPER, G proteincoupled estrogen receptor; LPBN, lateral parabrachial nucleus; LV, lateral ventricle; MR, mineralocorticoid receptors; NTS, nucleus of the solitary tractus.
}

\section{INTRODUCTION}

The ingestion of sodium is stimulated by body sodium deficiency and one of the main stimuli is the reninangiotensin-aldosterone system (Fregly and Rowland, 1985; Shade et al., 2002; Johnson and Thunhorst, 2007). Aldosterone is secreted by the adrenal cortex in response to increased plasma levels of angiotensin II (ANG II) and acts in the kidney to reduce renal sodium excretion and in the brain to stimulate sodium appetite (Fregly and Rowland, 1985; Sakai et al., 2000; Shade et al., 2002; Johnson and Thunhorst, 2007).

Early studies suggested the involvement of the amygdala on sodium appetite induced by systemic administration of aldosterone or deoxycorticosterone acetate (DOCA) (Nitabach et al., 1989; Galaverna et al., 1992; Zardetto-Smith et al., 1994). More recent studies have suggested the possible action of aldosterone in hindbrain areas to control sodium appetite (Geerling et al., 2006a,b; Geerling and Loewy, 2006c, 2007). Neuroanatomical studies identified neurons that express the enzyme 11- $\beta$-hydroxysteroid dehydrogenase 2 (HSD2 neurons) in the medial portion of the nucleus of the solitary tractus (NTS) near the 4th ventricle (4th V) (Geerling et al., 2006a,b; Geerling and Loewy, 2006c, 2007). The HSD2 neurons are sensitive only to aldosterone and are activated in sodium-depleted rats and deactivated by the ingestion of hypertonic $\mathrm{NaCl}$, suggesting that these neurons may play a role in the homeostasis of body sodium (Geerling et al., 2006b; Geerling and Loewy, 2006c). Functional studies showed that chronic infusion of low dose of aldosterone into the 4 th $\mathrm{V}$ strongly increased daily $1.8 \% \mathrm{NaCl}$ intake and the knockdown of mineralocorticoid receptors (MR) in the NTS reduced sodium intake induced by chronic infusion of aldosterone into the 4 th $\mathrm{V}$, suggesting the involvement of these NTS neurons in this behavioral response (Koneru et al., 2014).

Contrary to chronic infusion of aldosterone into the 4 th $\mathrm{V}$, acute injection of aldosterone into the 4 th $\mathrm{V}$ induces no sodium intake. The reasons for the absence of acute natriorexigenic effect of aldosterone are not clear. It is known that acute and chronic effects of aldosterone may involve different mechanisms (Booth et al., 2002). The acute effects of aldosterone that occur within seconds to minutes might involve non-genomic action on $\mathrm{G}$ protein-coupled estrogen receptor (GPER) (Funder, 2011; Gros et al., 2011), whereas chronic effects may involve genomic mechanisms. However, another reason 
for the delay in the natriorexigenic effect of aldosterone infused into the 4 th $\mathrm{V}$ might be the action of an inhibitory mechanism such as that mediated by the lateral parabrachial nucleus (LPBN). The LPBN receives neural input from different regions, including the area postrema (AP) and the nucleus of the solitary tract (NTS). The NTS is innervated by afferents from baroreceptors, cardiopulmonary receptors, gustatory receptors and other visceral receptors that influence water and $\mathrm{NaCl}$ intake (Lanca and van der Kooy, 1985; Johnson and Thunhorst, 1997; Johnson, 2007). The blockade of serotonin, cholecystokinin, corticotropin releasing factor or glutamate receptors or the activation $\alpha_{2}$ adrenergic receptors in the LPBN increases sodium intake and occasionally water drinking in fluid-depleted animals, suggesting the existence of a significant inhibitory mechanism in the LPBN controlling sodium and water intake (Menani et al., 1996; Menani and Johnson, 1998; Andrade et al., 2004; De Gobbi et al., 2007, 2009). The blockade of serotonin in the LPBN also increases DOCA-induced sodium intake (De Gobbi et al., 2000).

To investigate if the LPBN inhibitory mechanisms restrain sodium intake in rats that receive acute injections of aldosterone into the 4 th $\mathrm{V}$, in the present study, the ingestion of $1.8 \% \mathrm{NaCl}$ and water was tested in rats treated with aldosterone injection into the 4th $\mathrm{V}$ combined with the blockade of the inhibitory mechanisms using bilateral injections of methysergide (serotonergic antagonist) or moxonidine ( $\alpha_{2}$ adrenergic/ imidazoline receptor agonist) into the LPBN. To confirm the action of aldosterone in the hindbrain, it was also tested the ingestion of water and $1.8 \% \mathrm{NaCl}$ in rats treated with injection of aldosterone into the lateral ventricle (LV) combined with bilateral injections of moxonidine into the LPBN.

\section{MATERIAL AND METHODS}

\section{Animals}

Male Holtzman rats weighing 280-320 g were housed individually in stainless steel cages in a room with controlled temperature $\left(23 \pm 2{ }^{\circ} \mathrm{C}\right)$ and humidity (55 $\pm 10 \%$ ). Lights were on from 7:00 am to 7:00 pm. Normal rat chow (Biobase, Águas Frias, SC, Brazil, composed by $22 \mathrm{~g}$ of protein, $48 \mathrm{~g}$ of carbohydrates, $4 \mathrm{~g}$ of total fat, $8 \mathrm{~g}$ of fiber and $200 \mathrm{mg}$ of sodium per $100 \mathrm{~g}$ of diet), tap water and $1.8 \%(0.3 \mathrm{M}) \mathrm{NaCl}$ were available ad libitum. The experimental protocols used in the present study were approved by the Ethics Committee for Animal Care and Use from Dentistry School of Araraquara - UNESP.

\section{Brain surgery}

Rats were anesthetized with ketamine $(80 \mathrm{mg} / \mathrm{kg}$ of body weight i.p.) and xylazine ( $7 \mathrm{mg} / \mathrm{kg}$ of body weight i.p.). Stainless steel cannulas $(12 \times 0.6 \mathrm{~mm} \quad$ o.d. $)$ were implanted in the 4 th V or LV and bilaterally in the LPBN using a Kopf stereotaxic instrument. The stereotaxic coordinates for the LPBN were $9.4 \mathrm{~mm}$ caudal to the bregma, $2.1 \mathrm{~mm}$ lateral to midline and $4.1 \mathrm{~mm}$ below the dura mater with the tips of the cannulas at a point $2 \mathrm{~mm}$ above the LPBN. The coordinates for the 4 th $\mathrm{V}$ were $12.5 \mathrm{~mm}$ caudal to the bregma, $0.0 \mathrm{~mm}$ lateral to midline and $5.5 \mathrm{~mm}$ below the dura mater and for the LV were $0.6 \mathrm{~mm}$ caudal to the bregma, $1.6 \mathrm{~mm}$ lateral to midline and $3.6 \mathrm{~mm}$ below the dura mater. The cannulas were fixed to the cranium using dental acrylic resin and jeweler screws. Animals received an intramuscular injection of penicillin (30,000 IU) and a subcutaneous (s. c.) injection of the analgesic Ketoflex (ketoprofen 1\%, $0.03 \mathrm{ml} / \mathrm{rat}$ ) at the end of the surgery. Water and $\mathrm{NaCl}$ intake tests started one week after the surgery.

\section{Drugs}

Moxonidine hydrochloride, methysergide maleate and aldosterone purchased from Sigma Chemical Co, St. Louis, MO, USA were used. Moxonidine and methysergide were dissolved in propyleneglycol:distilled water (2:1) and aldosterone was dissolved in $1 \%$ ethanol in $0.9 \% \mathrm{NaCl}$. Moxonidine $(0.5 \mathrm{nmol} / 0.2 \mu \mathrm{l})$, methysergide $(4 \mu \mathrm{g} / 0.2 \mu \mathrm{l})$ or vehicle was injected into the LPBN and aldosterone $(250 \mathrm{ng} / 2 \mu \mathrm{l}$ or $250 \mathrm{ng} / 1 \mu \mathrm{l})$ or vehicle was injected into the 4 th $V$ and LV. The doses were based on previous studies that tested the effects of these drugs on water and sodium intake (Menani et al., 1998; Andrade et al., 2004; Formenti et al., 2013).

\section{Central injections}

Central injections were made using injector cannulas ( $0.3 \mathrm{~mm}$ o.d.) $2 \mathrm{~mm}$ longer than guide cannulas connected with a polyethylene tubing (PE-10 to a $10-\mu l$ Hamilton syringes. The volume of injection was $2 \mu$ into the 4th $V, 1 \mu \mathrm{l}$ into the LV and $0.2 \mu \mathrm{l}$ in each side of the LPBN.

\section{Histology}

At the end of the tests, the animals were anesthetized with sodium thiopental (60 mg/kg of body weight) and received injections of $2 \%$ Evans blue solution into the central sites. They were perfused transcardially with $10 \%$ formalin, brains were collected and fixed in $10 \%$ formalin. After at least two days, brains were frozen and cut into $60-\mu \mathrm{m}$ sections. To confirm the central sites of injections, sections were stained with Giemsa and analyzed by light microscopy.

\section{Statistical analysis}

Two-way repeated measures ANOVA and the NemanKeuls post-test were used to compare the results. Results were considered significantly different for $p$ $<0.05$. 


\section{PROTOCOL}

Sodium and water intake in rats treated with aldosterone $(500 \mathrm{ng}$ ) injected into the 4 th $\mathrm{V}$ combined with bilateral injections of moxonidine into the LPBN

Rats with cannulas implanted in the 4 th $\mathrm{V}$ and bilaterally in the $L P B N$ received aldosterone injection $(250 \mathrm{ng} / 2 \mu \mathrm{l})$ into the 4th V. Forty-five minutes later, the animals received bilateral injections of moxonidine $(0.5 \mathrm{nmol} / 0.2 \mu \mathrm{l})$ or vehicle into the LPBN. Fifteen minutes after LPBN injections the animals received a second injection of aldosterone $(250 \mathrm{ng} / 2 \mu \mathrm{l})$ into the 4 th $\mathrm{V}$, reaching a total of $500 \mathrm{ng}$ of aldosterone into the $4 \mathrm{th} \mathrm{V}$. Then, burettes containing water and $1.8 \% \mathrm{NaCl}$ were offered to the animals. Water and $1.8 \% \mathrm{NaCl}$ intake was measured every thirty minutes for two hours. Two groups of rats were used in these tests. The first group of rats tested received only two combinations of treatments: (1) Aldosterone 4th $\mathrm{V}+$ vehicle LPBN; (2) aldosterone 4th $\mathrm{V}+$ moxonidine LPBN in two tests. The second group of rats tested received four combinations of treatments: (1) Vehicle 4th V + vehicle LPBN; (2) aldosterone 4th $\mathrm{V}+$ vehicle LPBN; (3) aldosterone 4th $\mathrm{V}+$ moxonidine LPBN; (4) vehicle 4th $V+$ moxonidina LPBN in four tests. In each test the groups of rats were divided into two subgroups and each subgroup received one of the combinations of treatments. The sequence of combinations of treatment that each rat received in different tests was randomized and at the end of the experiments the rats received two combinations or four combinations of treatments. The results of the two groups of rats were analyzed together.

\section{Sodium and water intake in rats treated with} aldosterone $(250 \mathrm{ng})$ injected into the 4 th $\mathrm{V}$ combined with bilateral injections of moxonidine into the LPBN

Another group of animals received the same 4 combinations of treatments described above, except that they received only one injection of aldosterone $(250 \mathrm{ng} / 2 \mu)$ into the 4 th $\mathrm{V} 15 \mathrm{~min}$ after moxonidine $(0.5 \mathrm{nmol} / 0.2 \mu \mathrm{l})$ injections into the LPBN.

\section{Sodium and water intake in rats treated with} aldosterone ( $250 \mathrm{ng}$ ) injected into the 4 th $\mathrm{V}$ combined with bilateral injections of methysergide into the LPBN

Another group of animals received the same 4 combinations of treatments described above, except that they received only one injection of aldosterone $(250 \mathrm{ng} / 2 \mu \mathrm{l})$ into the 4 th $\mathrm{V} 15 \mathrm{~min}$ after methysergide $(4 \mu \mathrm{g} / 0.2 \mu \mathrm{l})$ injections into the LPBN.

\section{Sodium and water intake in rats treated with} aldosterone (500 $\mathrm{ng}$ ) injected into the LV combined with bilateral injections of moxonidine into the LPBN

Another group of animals received the same 4 combinations of treatments described above, except that aldosterone was injected into the LV instead of the 4th V.

\section{RESULTS}

\section{Histology}

Fig. 1A shows the tract of the cannula directed to the 4 th $V$ and Fig. 1B shows the typical sites of injections into the LPBN. The injections into the 4 th $V$ were close to the intermediate NTS, the region in which HSD2 neurons are located. The position of the injections was at coordinates similar to those of previous studies that tested the effects of infusions of aldosterone into the 4th $\mathrm{V}$ on sodium intake (Formenti et al., 2013). The LPBN injection sites were centered in the central lateral or dorsal lateral portions of the LPBN (see Fulwiler and Saper, 1984, for definitions of the LPBN subnuclei) (Fulwiler and Saper, 1984). The sites of the injections into the LPBN in the present study were similar to those of previous studies showing the effects of the injections of methysergide, moxonidine or noradrenaline into the LPBN on $\mathrm{NaCl}$ and water intake (Menani et al., 1996, 1998; Fratucci De Gobbi et al., 2001; Andrade et al., 2004; De Gobbi et al., 2007, 2009; Gasparini et al., 2009).

Sodium and water intake in rats treated acutely with aldosterone into the 4th $\mathrm{V}$ combined with bilateral injections of moxonidine into the LPBN

Injections of aldosterone (500 ng) into the 4 th $\mathrm{V}$ combined with vehicle into the LPBN did not alter $1.8 \% \mathrm{NaCl}$ intake
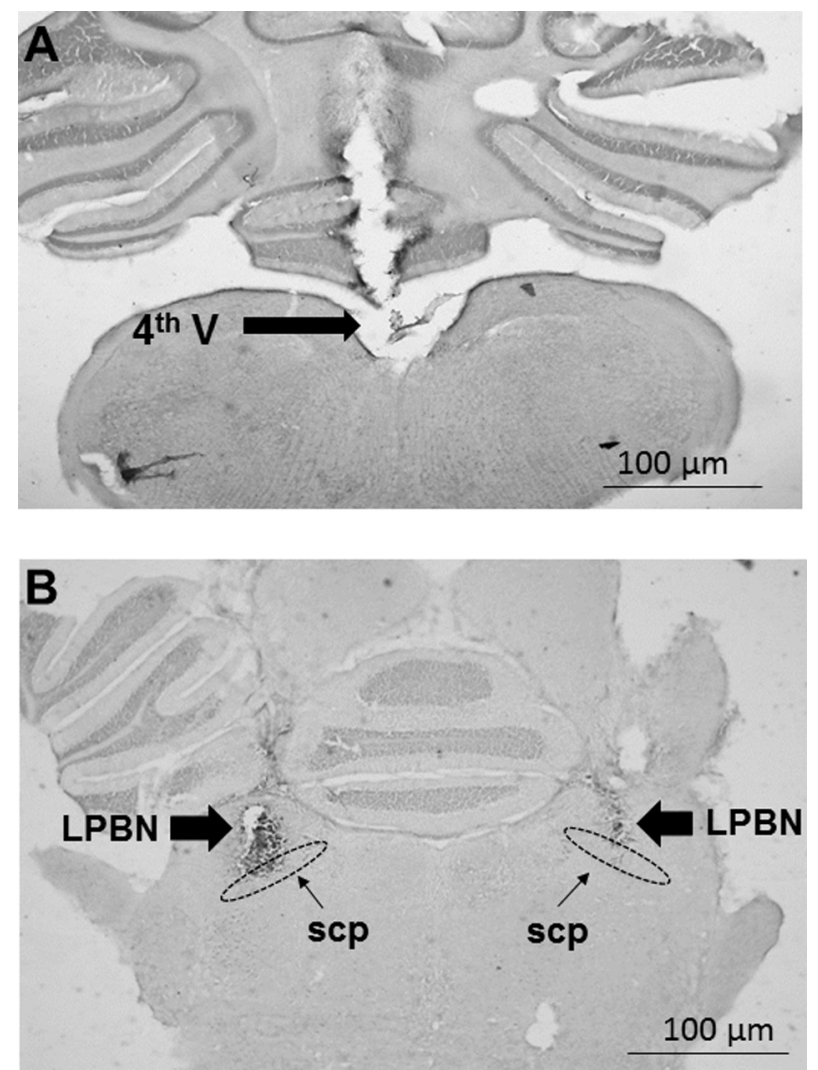

Fig. 1. Photomicrographs of coronal sections of a rat brain showing the injection sites into the (A) 4th V and (B) LPBN (arrows). scp, superior cerebellar peduncle. 
$(1.1 \pm 0.4 \mathrm{ml} / 2 \mathrm{~h})$ compared to vehicle into the 4th $\mathrm{V}$ + vehicle into the LPBN $(0.5 \pm 0.5 \mathrm{ml} / 2 \mathrm{~h})$. However, injections of aldosterone $(500 \mathrm{ng})$ into the 4 th $\mathrm{V}$ combined with moxonidine $(0.5 \mathrm{nmol} / 0.2 \mu \mathrm{l})$ injected bilaterally into the LPBN strongly increased $1.8 \% \mathrm{NaCl}$ intake $(17.6 \pm 3.7 \mathrm{ml} / 2 \mathrm{~h})[F(3,96)=47.68 ; p<0.05]$ (Fig. 2A.). Injections of moxonidine bilaterally into the LPBN combined with vehicle into the 4 th $\mathrm{V}$ also did not modify $1.8 \% \mathrm{NaCl}$ intake $(1.3 \pm 1.1 \mathrm{ml} / 2 \mathrm{~h})$.

The combination of aldosterone (250 ng) injected into the 4th $\mathrm{V}$ with moxonidine $(0.5 \mathrm{nmol} / 0.2 \mu \mathrm{l})$ injected bilaterally into the LPBN also increased $1.8 \% \mathrm{NaCl}$ intake $(12.7 \pm 4.6$, vs. vehicle into LPBN + vehicle into 4th $V: 1.0 \pm 0.5 \mathrm{ml} / 2 \mathrm{~h}) \quad[F(3,15)=5.19 ; p<0.05]$ (Table 1). Vehicle into the LPBN + aldosterone into the 4th $\mathrm{V}$ or moxonidine into the LPBN + vehicle into the 4th $\mathrm{V}$ did not change $1.8 \% \mathrm{NaCl}$ intake $(1.5 \pm 1.1$ and $2.3 \pm 1.6 \mathrm{ml} / 2 \mathrm{~h}$, respectively).

Water intake also increased in the animals treated with aldosterone $(500 \mathrm{ng})$ into the 4 th $\mathrm{V}$ combined with bilateral injections of moxonidine into the LPBN $(6.8$ $\pm 2.1 \mathrm{ml} / 2 \mathrm{~h}$ ) compared to vehicle injected into the 4th $\mathrm{V}+$ vehicle into the $\operatorname{LPBN}(0.4 \pm 0.4 \mathrm{ml} / 2 \mathrm{~h})[F(3,96)$ $=9.56 ; p<0.05$ ] (Fig. 2B). However, water intake did not change in animals treated with aldosterone $(250 \mathrm{ng})$ into the 4th $V+$ moxonidine into the LPBN $(2.5 \pm 0.9$, vs. vehicle into the LPBN + vehicle into the 4th $\mathrm{V}: 1.3$ $\pm 0.7 \mathrm{ml} / 2 \mathrm{~h})[F(3,15)=5.41 ; p>0.05]$ (Table 1). Aldosterone (250 or $500 \mathrm{ng}$ ) injected into the 4th $\mathrm{V}$ + vehicle into LPBN did not affect water intake (0.8 \pm 0.3 and $1.9 \pm 0.7 \mathrm{ml} / 2 \mathrm{~h}$, respectively). Moxonidine injected into LPBN + vehicle into 4th $\mathrm{V}$ also did not change water intake(Fig. 2B, Table 1).

Water and sodium intake in rats treated acutely with aldosterone into the 4th $\mathrm{V}$ combined with bilateral injections of methysergide into the LPBN

Aldosterone (250 $\mathrm{ng}$ ) injected into the 4th $\mathrm{V}$ combined with methysergide $(4 \mu \mathrm{g})$ injected into the LPBN also strongly increased $1.8 \% \mathrm{NaCl}$ intake $(17.6 \pm 5.4 \mathrm{ml} / 2 \mathrm{~h})$ compared to vehicle into the 4th $\mathrm{V}+$ vehicle into the LPBN $(1.3 \pm 0.6 \mathrm{ml} / 2 \mathrm{~h}) \quad[F(3,24)=7.57 ; p<0.05]$ (Fig. $2 \mathrm{C}$ ), without changing water intake (3.3 \pm 1.3 , vs. vehicle into the 4 th $\mathrm{V}+$ vehicle into the LPBN: 0.7 $\pm 0.3 \mathrm{ml} / 2 \mathrm{~h})[F(3,24)=1.90 ; p>0.05]$ (Fig. 2D).

The treatment with aldosterone $(250 \mathrm{ng})$ into the 4 thV + vehicle into the LPBN did not modify $1.8 \% \mathrm{NaCl}$ intake $(1.5 \pm 0.7 \mathrm{ml} / 2 \mathrm{~h})$ or water intake $(1.1 \pm 0.4 \mathrm{ml} / 2 \mathrm{~h})$ (Fig. 2C, D).

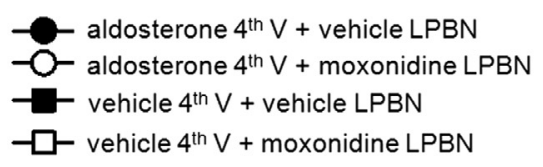

* different from vehicle $4^{\text {th }} \mathrm{V}+$ vehicle LPBN
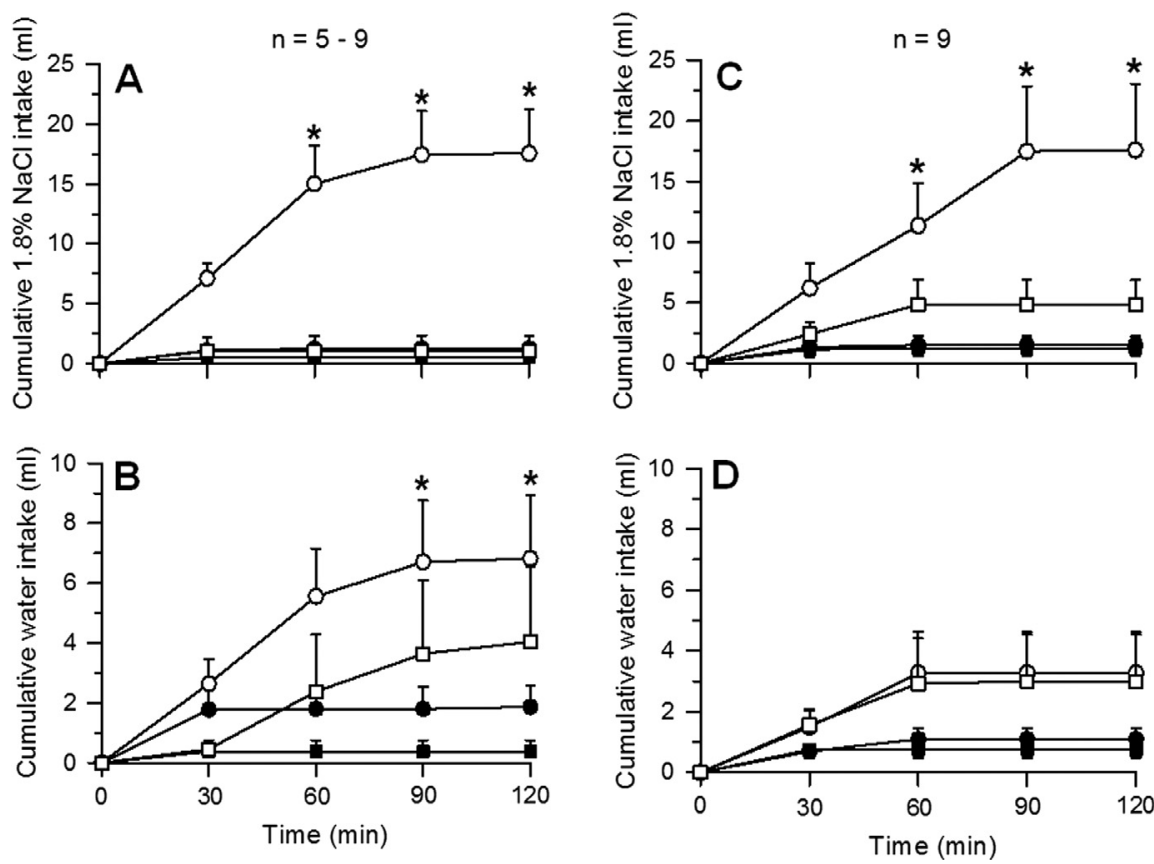

Fig. 2. Cumulative $(A, C) 1.8 \% \mathrm{NaCl}$ and $(B, D)$ water intake in rats that received injections of $(A, B)$ aldosterone $(500 \mathrm{ng} / 2 \mu \mathrm{l})$ or vehicle into the 4 th $\mathrm{V}$ combined with bilateral injections of moxonidine $(0.5 \mathrm{nmol} / 0.2 \mu \mathrm{l})$ or vehicle into the LPBN or $(\mathrm{C}, \mathrm{D})$ aldosterone $(250 \mathrm{ng} / 2 \mu \mathrm{l})$ or vehicle into the 4 th $\mathrm{V}$ combined with bilateral injections of methysergide $(4 \mu \mathrm{g} / 0.2 \mu \mathrm{l})$ or vehicle into the LPBN. The results are expressed as means $\pm \mathrm{SEM}, n=$ number of animals.

\section{Water and sodium intake in rats treated acutely with aldosterone injection into the LV combined with bilateral injections of moxonidine into the LPBN}

Injection of aldosterone $(250 \mathrm{ng} / 1 \mu \mathrm{l})$ into the LV combined with moxonidine $(0.5 \mathrm{nmol} / 0.2 \mu \mathrm{l})$ injected bilaterally into the LPBN did not change $1.8 \% \mathrm{NaCl}$ intake $(0.2$ $\pm 0.1 \mathrm{ml} / 2 \mathrm{~h}$ ) when compared with vehicle injections into the LV + vehicle into the LPBN $(0.3$ $\pm 0.2 \mathrm{ml} / 2 \mathrm{~h}) \quad[F(3, \quad 12)=1.99$; $p>0.05$ ] (Table 2).

Water intake was also not modified by the treatment with aldosterone into the LV + moxonidine into the LPBN $(0.2$ \pm 0.1 , vs. vehicle into the LV + vehicle into the LPBN: 0.5 $\pm 0.2 \mathrm{ml} / 2 \mathrm{~h}) \quad[F(3,12)=0.48$; $p>0.05$ ] (Table 2).

Aldosterone injected into the LV + vehicle into the LPBN or vehicle into the $\mathrm{LV}+$ moxonidine into the LPBN did not change $1.8 \% \mathrm{NaCl}$ or water intake (Table 2).

\section{DISCUSSION}

A previous study showed strong increase in daily ingestion of $1.8 \%$ $\mathrm{NaCl}$ in rats treated with chronic infusion of low dose of aldosterone 
Table 1. Water and $1.8 \% \mathrm{NaCl}$ intake in rats that received aldosterone or vehicle injection into 4 th $\mathrm{V}+$ bilateral injections of moxonidine or vehicle into LPBN

\begin{tabular}{lll}
\hline Treatment & $1.8 \% \mathrm{NaCl}$ intake $(\mathrm{ml} / 2 \mathrm{~h})$ & Water $(\mathrm{ml} / 2 \mathrm{~h})$ \\
\hline Aldosterone 4th V + vehicle LPBN & $1.5 \pm 1.1$ & $0.8 \pm 0.3$ \\
Aldosterone 4th V + moxonidine LPBN & $12.7 \pm 4.6^{*}$ & $2.5 \pm 0.9$ \\
Vehicle 4th V + vehicle LPBN & $1.0 \pm 0.5$ & $1.3 \pm 0.3$ \\
Vehicle 4th V + moxonidine LPBN & $2.3 \pm 1.6$ & $0.5 \pm 0.4$ \\
\hline
\end{tabular}

The results are expressed as means \pm SEM, $\mathrm{n}=5$. Moxonidine $(0.5 \mathrm{nmol} / 0.2 \mu \mathrm{l})$ and aldosterone $(250 \mu \mathrm{g} / 1 \mu \mathrm{l}) .{ }^{*}$ Different from vehicle + vehicle $(p<0.05)$.

Table 2. Water and $1.8 \% \mathrm{NaCl}$ intake in rats that received aldosterone or vehicle injection into $\mathrm{LV}+$ bilateral injections of moxonidine or vehicle into LPBN

\begin{tabular}{lll}
\hline Treatment & $1.8 \% \mathrm{NaCl}$ intake $(\mathrm{ml} / 2 \mathrm{~h})$ & Water $(\mathrm{ml} / 2 \mathrm{~h})$ \\
\hline Aldosterone LV + vehicle LPBN & $0.3 \pm 0.5$ & $0.5 \pm 0.2$ \\
Aldosterone LV + moxonidine LPBN & $0.2 \pm 0.1$ & $0.2 \pm 0.1$ \\
Vehicle LV + vehicle LPBN & $0.3 \pm 0.2$ & $0.5 \pm 0.2$ \\
Vehicle LV + moxonidine LPBN & $0.7 \pm 0.4$ & $0.6 \pm 0.2$ \\
\hline
\end{tabular}

The results are expressed as mean \pm SEM, $n=5$. Moxonidine $(0.5 \mathrm{nmol} / 0.2 \mu \mathrm{l})$ and aldosterone $(250 \mu \mathrm{g} / 1 \mu \mathrm{l})$.

into the 4th V (Formenti et al., 2013). The present results extend those of the previous study showing that acute injections of aldosterone into the 4th $V$ combined with the deactivation of the inhibitory mechanisms with serotonergic blockade or $\alpha_{2}$ adrenergic receptor activation in the LPBN rapidly stimulate strong $1.8 \% \mathrm{NaCl}$ intake in the next two hours in satiated and normovolemic rats. The acute aldosterone injections into the 4 th $\mathrm{V}$ or the deactivation of the LPBN inhibitory mechanisms alone did not stimulate sodium intake. These results suggest that the activity of the LPBN mechanisms inhibits the facilitatory mechanisms and, therefore, sodium intake produced by acute injections of aldosterone into the hindbrain.

Water intake increased in animals treated with the high dose of aldosterone into the 4th $V$ combined with moxonidine injections into the LPBN, however, it was not modified by moxonidine or methysergide into the LPBN + low dose of aldosterone into the 4th V. The increase in water intake in animals that simultaneously ingest water and hypertonic $\mathrm{NaCl}$ is probably caused by the increase in plasma osmolality produced by the ingestion of hypertonic $\mathrm{NaCl}$ and not a direct effect of 4th $\mathrm{V}$ aldosterone. Although animals treated with methysergide or moxonidine into the LPBN combined with low dose of aldosterone into the 4th $\mathrm{V}$ also ingested significant amount of hypertonic saline, water intake did not increase. It is not clear the reason for the different effects of methysergide or moxonidine into the LPBN on water intake in rats treated with aldosterone into the 4th $\mathrm{V}$. Different studies have shown that the increase in water intake with methysergide injected into the LPBN when rats simultaneously ingest hypertonic $\mathrm{NaCl}$ is not consistent and only in part of the tests with methysergide into the LPBN water intake significantly increased in this condition(Menani et al., 1996, 2000, 2002; De Luca et al., 2003). Although water intake increased in rats treated with moxonidine combined with high dose of aldosterone into the 4th $\mathrm{V}$, the increase in water intake with moxonidine injected into the LPBN is also not consistent (Andrade et al., 2004, 2006, 2007, $2011,2015)$, which suggests that rats are driven to ingest sodium in detriment to water when they receive methysergide or moxonidine into the LPBN, probably as a consequence of the strong preference for sodium in this condition. Chronic infusion of aldosterone into the 4th $\mathrm{V}$ also strongly increases hypertonic $\mathrm{NaCl}$ intake, without significant changes in water intake (Formenti et al., 2013), which confirms that the ingestion of significant amounts of hypertonic $\mathrm{NaCl}$ not necessarily causes increases in water intake if rats are motivated to ingest sodium. Therefore, tests with only water available are necessary for a definitive conclusion about the effects of these treatments on water intake. Different from the effects produced by aldosterone injections into the 4 th $\mathrm{V}$, the same treatment into the LV combined or not with the blockade of LPBN inhibitory mechanisms changed neither sodium nor water intake, which suggests that the effect of aldosterone on sodium intake is limited to hindbrain structures. This reinforces previous results showing that aldosterone at the same doses that increase daily sodium intake when infused into the 4 th $V$, produces no change on daily sodium intake when infused into the LV. Although aldosterone infused or injected into the LV may reach the 4th $V$, the concentration of aldosterone in the 4 th $V$ after injections or infusions into the LV are probably not enough to produce effects.

Aldosterone effects depend on activation of genomic or non-genomic mechanisms (Booth et al., 2002). The acute effects of aldosterone, like sodium intake in the present study, probably involve non-genomic mechanisms, starting within seconds to minutes, without involving transcription and protein synthesis (Vinson and Coghlan, 2010; Feldman and Gros, 2011; Wendler et al., 2012). The non-genomic effects of aldosterone may depend on interaction with the GPER (Funder, 2011; Gros et al., 2011; Barton and Prossnitz, 2015). The GPER are located in the NTS and hypothalamic regions, such as supraoptic nucleus (SON), paraventricular nucleus (PVN) and arcuate nucleus (Brailoiu et al., 2007). In the 
present study, the involvement of GEPR on sodium intake produced by aldosterone injections into the 4th $\mathrm{V}$ was not tested, but considering the possibility that non-genomic mechanisms are involved in this behavior, it is not possible to exclude these receptors as those activated by aldosterone infused into the 4th V. The HSD2 neurons sensitive only to aldosterone are also present in the NTS and are candidate to be activated by aldosterone injected into the 4th $\mathrm{V}$. These neurons are activated in sodium-depleted rats and deactivated by ingestion of hypertonic $\mathrm{NaCl}$, which suggests that they may have a function controlling sodium intake (Geerling et al., 2006b; Geerling and Loewy, 2006c). The HSD2 neurons project to different nuclei like the LPBN, central nucleus of amygdala ( $\mathrm{CeA}$ ) and hypothalamus (Geerling and Loewy, 2006a,b) and might modulate excitatory or inhibitory pathways regulating sodium appetite.

The present results suggest that aldosterone acting in the hindbrain and possibly in the NTS activates facilitatory mechanisms that are counterbalanced by the action of the LPBN inhibitory mechanisms. Moxonidine or methysergide into the LPBN deactivates the inhibitory mechanisms releasing the action of the facilitatory mechanisms activated by aldosterone acting in the hindbrain, which drives rats to ingest sodium rapidly. The intensity of the facilitatory signals produced by the acute treatment with aldosterone alone into the 4 th $\mathrm{V}$ is probably low and not enough to overcome the inhibitory mechanisms present in satiated and normovolemic rats resulting in no sodium intake. On the contrary, with chronic infusion of aldosterone into the 4th $\mathrm{V}$, the facilitatory signals are probably predominant, driving rats to ingest sodium. With aldosterone acting chronically in the hindbrain the facilitation of sodium intake may result from increases in facilitatory signals and/or deactivation the inhibitory mechanisms. More studies are necessary to test these hypotheses.

The involvement of LPBN mechanisms in the control of mineralocorticoid-induced sodium intake was previously suggested for DOCA-induced sodium appetite (De Gobbi et al., 2000). In animals treated with DOCA, that had daily access to $1.8 \% \mathrm{NaCl}$ during $2 \mathrm{~h}$ for several days, bilateral injections of methysergide into the LPBN increased $1.8 \% \mathrm{NaCl}$ intake and water intake in response to DOCA administration. On the contrary, injections of the serotonergic $5 \mathrm{HT}_{2 \mathrm{~A} / 2 \mathrm{C}}$ receptor agonist $\mathrm{DOI}$ into the $\mathrm{LPBN}$ reduced $1.8 \% \mathrm{NaCl}$ intake. Previously it was also shown that $\alpha_{2}$ adrenergic receptor activation in the LPBN deactivates the inhibitory mechanisms increasing sodium intake in fluid-depleted rats (Menani et al., 1996; Menani and Johnson, 1998; Andrade et al., 2004; De Castro e Silva et al., 2006; De Gobbi et al., 2007, 2009). The present results extend those of previous studies showing that aldosterone injected into the 4th $\mathrm{V}$ combined with the deactivation of inhibitory mechanisms with either activation of $\alpha_{2}$ adrenergic receptors or inhibition of serotonergic mechanisms in the LPBN strong increased sodium intake acutely.

The LPBN receives signals from the area postrema and NTS that may influence water and $\mathrm{NaCl}$ intake, like signals from baroreceptors, cardiopulmonary receptors, gustatory receptors and other visceral receptors (Lanca and van der Kooy, 1985; Johnson and Thunhorst, 1997; Johnson, 2007). In the LPBN, these signals may modulate an important inhibitory mechanism for sodium and water intake (Menani et al., 2014). The LPBN sends projections to different forebrain areas involved in the control of water and sodium intake, among them the CeA (Ciriello et al., 1984; Fulwiler and Saper, 1984; Jhamandas et al., 1996). Lesions of the CeA reduce daily sodium intake or that induced by ANG II or mineralocorticoids, suggesting that important facilitatory mechanisms for sodium intake are present in the CeA (Galaverna et al., 1992; Zardetto-Smith et al., 1994). Recent studies have also shown that the blockade of neuronal activity of the $\mathrm{CeA}$ with the GABAA agonist muscimol or the antagonism of the opioid receptors with naloxone abolished the increase of sodium intake in rats treated with FURO + CAP combined with the blockade of the LPBN inhibitory mechanisms, suggesting that the LPBN may inhibit CeA mechanisms that facilitate sodium intake (Andrade et al., 2015). It was also suggested that the CeA receives projections from the NTS and particularly from the HSD2 neurons of the NTS (Geerling and Loewy, 2006a). Therefore, facilitatory signals produced by aldosterone infused or injected into the 4 th $\mathrm{V}$ that reach the CeA or other forebrain areas might be under the inhibitory action of the LPBN. Removing or reducing this inhibitory action with injections of moxonidine or methysergide into the LPBN results in increased sodium intake when aldosterone is injected into the 4th $\mathrm{V}$.

A previous study (Formenti et al., 2013) showed that the injection of an aldosterone receptor antagonist (RU 28318) into the 4th $\mathrm{V}$, but not into the LV, strongly reduced $1.8 \% \mathrm{NaCl}$ intake induced by sodium depletion (diuretic + low-sodium diet for $24 \mathrm{~h}$ ) or low-sodium diet for nine days, which suggests that the activation of the MR located in the hindbrain is a physiological mechanism activated to induce sodium intake in different models used to test sodium appetite. A study testing fluid eletrolyte balance showed that chronic infusion of aldosterone into the 4th $\mathrm{V}$ in rats that had access to $1.8 \% \mathrm{NaCl}$ to ingest produced sodium intake, positive sodium balance and increased urinary volume and sodium excretion, without changes in the total fluid balance (unpublished results). However, the renal sodium excretion was similar to control animals when rats treated with chronic infusion of aldosterone into the 4 th $\mathrm{V}$ had no access to hypertonic $\mathrm{NaCl}$, which suggests that aldosterone into the 4th $\mathrm{V}$ clearly acts in the mechanisms that control sodium appetite as a primary response and the intake is not secondary to changes in renal excretion or in the body fluid volume. Aldosterone into the 4 th $\mathrm{V}$ also produces no change in arterial pressure, which excludes the involvement of cardiovascular signals in the natriorexigenic response to aldosterone into the 4 th $\mathrm{V}$. On the hand, previous studies showed that the deactivation of the LPBN mechanisms with injections of moxonidine or methysergide into the LPBN reduced renal excretion of sodium and water, which suggests that LPBN mechanisms act facilitating renal excretion (Margatho et al., 2007; Andrade et al., 2012). Therefore, previous results suggest that LPBN 
mechanisms reducing sodium ingestion and increasing the excretion prevent the expansion of body fluid volume (Andrade et al., 2014, Menani et al., 2014). The present results suggest for the first time that the natriorexigenic signals produced by aldosterone acting in the hindbrain are also inhibited by LPBN mechanisms. This might be a reason why chronic infusion of aldosterone into the 4th $\mathrm{V}$ produces strong ingestion of sodium, whereas acute injection of aldosterone into the 4th $V$ produces sodium intake only if the LPBN mechanisms are deactivated with the injection of moxonidine or methysergide in this area. With the chronic infusion of aldosterone, the natriorexigenic signals are probably strong enough to overcome the inhibitory action of the LPBN, whereas with acute dose of aldosterone this is not possible.

In conclusion, the present results show that acute treatment with aldosterone injected into the 4th $\mathrm{V}$ combined with deactivation of the LPBN inhibitory mechanisms immediately drives satiated and normovolemic rats to ingest strong amounts of hypertonic $\mathrm{NaCl}$, a response not present if these rats receive only aldosterone injection into the 4th $V$ or only the deactivation of the LPBN with moxonidine or methysergide injections into this area. These results suggest that facilitatory mechanisms for sodium intake activated by aldosterone acting in the hindbrain are under the control of the LPBN inhibitory mechanisms. The results clearly extend the action of the LPBN mechanisms to the control of mineralocorticoid-induced sodium intake, an important physiological facilitatory mechanism involved in the control of this behavior. More studies are necessary to demonstrate if GPERs are involved in the acute and chronic effects of aldosterone injected into the 4th $V$ and where these receptors are located. Other question that needs to be addressed is the reason for the differences between acute and chronic effects of aldosterone into the 4th $V$ on sodium intake. If chronic treatment with aldosterone into the 4th $\mathrm{V}$ increases natriorexigenic signals at a point that they overcome the inhibitory signals of the LPBN or if aldosterone chronically into the 4 th $V$ reduces the action of the LPBN mechanisms causing increased daily sodium intake.. Another issue to be investigated is if $\mathrm{CeA}$ is important for sodium intake produced by acute and chronic treatment with aldosterone into the 4 th $\mathrm{V}$.

\section{FUNDING}

This research was supported by Conselho Nacional de Desenvolvimento Científico e Tecnológico (CNPq), Fundação de Amparo à Pesquisa do Estado de São Paulo (FAPESP 2011/50770-1, FAPESP 2013/00026-0; 2015/23467-7), PROPE-UNESP.

\section{AUTHOR CONTRIBUTIONS}

Conception and format of the paper was made by SG and MRS. Acquisition, analysis, or interpretation of data was made by SG, MRM, GFL, PAN, GMFAF, JVM and EC. SG drafted the article and MRM, GMFAF, JVM and EC revised it critically for important intellectual content. All authors approved the final version of the manuscript, agree to be accountable for all aspects of the work in ensuring that questions related to the accuracy or integrity of any part of the work are appropriately investigated and resolved. All persons designated as authors qualify for authorship, and all those who qualify for authorship are listed.

Acknowledgments-The authors thank Dr. Willis K. Samson for the suggestions and corrections to improve the manuscript, Silvana A. D. Malavolta and Carla Molina for secretarial assistance and Mikail Douglas dos Santos and Ana V. Oliveira for animal care.

\section{REFERENCES}

Andrade CA, Andrade-Franze GM, De Luca Jr LA, Johnson AK, Menani JV (2011) Changes in taste reactivity to intra-oral hypertonic $\mathrm{NaCl}$ after lateral parabrachial injections of an alpha2-adrenergic receptor agonist. Physiol Behav 104:702-708.

Andrade CA, Andrade-Franze GM, De Paula PM, De Luca LA, Menani Jr JV (2014) Role of alpha2-adrenoceptors in the lateral parabrachial nucleus in the control of body fluid homeostasis. Braz J Med Biol Res 47:11-18.

Andrade CA, Barbosa SP, De Luca LA, Menani Jr JV (2004) Activation of alpha2-adrenergic receptors into the lateral parabrachial nucleus enhances $\mathrm{NaCl}$ intake in rats. Neuroscience 129:25-34.

Andrade CA, De Luca LA, Colombari Jr DS, Menan Jr JV (2006) Alpha2-adrenergic activation in the lateral parabrachial nucleus induces $\mathrm{NaCl}$ intake under conditions of systemic hyperosmolarity. Neuroscience 142:21-28.

Andrade CA, De Luca LA, Colombari Jr DS, Menan Jr JV (2007) Enhancement of meal-associated hypertonic $\mathrm{NaCl}$ intake by moxonidine into the lateral parabrachial nucleus. Behav Brain Res 183:156-160.

Andrade CA, De Oliveira LB, Andrade-Franze GM, De Luca LA, Colombari Jr DS, Menan Jr JV (2015) Gabaergic and opioid receptors mediate the facilitation of $\mathrm{NaCl}$ intake induced by alpha (2)-adrenergic activation in the lateral parabrachial nucleus. Behav Brain Res 278:535-541.

Andrade CA, Margatho LO, Andrade-Franze GM, De Luca Jr LA, Antunes-Rodrigues J, Menani JV (2012) Moxonidine into the lateral parabrachial nucleus reduces renal and hormonal responses to cell dehydration. Neuroscience 208:69-78.

Barton M, Prossnitz ER (2015) Emerging roles of GPER in diabetes and atherosclerosis. Trends Endocrinol Metab 26:185-192.

Booth RE, Johnson JP, Stockand JD (2002) Aldosterone. Adv Physiol Educ 26:8-20.

Brailoiu E, Dun SL, Brailoiu GC, Mizuo K, Sklar LA, Oprea TI, Prossnitz ER, Dun NJ (2007) Distribution and characterization of estrogen receptor $\mathrm{G}$ protein-coupled receptor 30 in the rat central nervous system. J Endocrinol 193:311-321.

Ciriello J, Lawrence D, Pittman QJ (1984) Electrophysiological identification of neurons in the parabrachial nucleus projecting directly to the hypothalamus in the rat. Brain Res 322:388-392.

De Castro e Silva E, Fregoneze JB, Johnson AK (2006) Corticotropin-releasing hormone in the lateral parabrachial nucleus inhibits sodium appetite in rats. Am J Physiol Regul Integr Comp Physiol 290:R1136-R1141.

De Gobbi JI, Beltz TG, Johnson RF, Menani JV, Thunhorst RL, Johnson AK (2009) Non-NMDA receptors in the lateral parabrachial nucleus modulate sodium appetite. Brain Res 1301:44-51.

De Gobbi JI, De Luca LA, Menani Jr JV (2000) Serotonergic mechanisms of the lateral parabrachial nucleus on DOCAinduced sodium intake. Brain Res 880:131-138.

De Gobbi JI, Martinez G, Barbosa SP, Beltz TG, De Luca Jr LA, Thunhorst RL, Johnson AK, Vanderlei Menani J (2007) 5-HT2 and 
5-HT3 receptors in the lateral parabrachial nucleus mediate opposite effects on sodium intake. Neuroscience 146:1453-1461.

De Luca Jr LA, Barbosa SP, Menani JV (2003) Brain serotonin blockade and paradoxical salt intake in rats. Neuroscience 121:1055-1061.

Feldman RD, Gros R (2011) Unraveling the mechanisms underlying the rapid vascular effects of steroids: sorting out the receptors and the pathways. Br J Pharmacol 163:1163-1169.

Formenti S, Bassi M, Nakamura NB, Schoorlemmer GH, Menani JV, Colombari E (2013) Hindbrain mineralocorticoid mechanisms on sodium appetite. Am J Physiol Regul Integr Comp Physiol 304: R252-R259.

Fratucci De Gobbi JI, De Luca Jr LA, Johnson AK, Menani JV (2001) Interaction of serotonin and cholecystokinin in the lateral parabrachial nucleus to control sodium intake. Am J Physiol Regul Integr Comp Physiol 280:R1301-R1307.

Fregly MJ, Rowland NE (1985) Role of renin-angiotensin-aldosterone system in $\mathrm{NaCl}$ appetite of rats. Am J Physiol 248:R1-R11.

Fulwiler CE, Saper CB (1984) Subnuclear organization of the efferent connections of the parabrachial nucleus in the rat. Brain Res 319:229-259.

Funder JW (2011) GPR30, mineralocorticoid receptors, and the rapid vascular effects of aldosterone. Hypertension 57:370-372.

Galaverna O, De Luca Jr LA, Schulkin J, Yao SZ, Epstein AN (1992) Deficits in $\mathrm{NaCl}$ ingestion after damage to the central nucleus of the amygdala in the rat. Brain Res Bull 28:89-98.

Gasparini S, de Luca Jr LA, Colombari DS, de Paula PM, Barbosa SP, Menani JV (2009) Adrenergic mechanisms of the KollikerFuse/A7 area on the control of water and sodium intake. Neuroscience 164:370-379.

Geerling JC, Engeland WC, Kawata M, Loewy AD (2006a) Aldosterone target neurons in the nucleus tractus solitarius drive sodium appetite. J Neurosci 26:411-417.

Geerling JC, Kawata M, Loewy AD (2006b) Aldosterone-sensitive neurons in the rat central nervous system. J Comp Neurol 494:515-527.

Geerling JC, Loewy AD (2006a) Aldosterone-sensitive neurons in the nucleus of the solitary tract: bidirectional connections with the central nucleus of the amygdala. J Comp Neurol 497:646-657.

Geerling JC, Loewy AD (2006b) Aldosterone-sensitive neurons in the nucleus of the solitary: efferent projections. J Comp Neurol 498:223-250.

Geerling JC, Loewy AD (2006c) Aldosterone-sensitive NTS neurons are inhibited by saline ingestion during chronic mineralocorticoid treatment. Brain Res 1115:54-64.

Geerling JC, Loewy AD (2007) Sodium depletion activates the aldosterone-sensitive neurons in the NTS independently of thirst. Am J Physiol Regul Integr Comp Physiol 292:R1338-R1348.

Gros R, Ding Q, Sklar LA, Prossnitz EE, Arterburn JB, Chorazyczewski J, Feldman RD (2011) GPR30 expression is required for the mineralocorticoid receptor-independent rapid vascular effects of aldosterone. Hypertension 57:442-451.

Jhamandas JH, Petrov T, Harris KH, Vu T, Krukoff TL (1996) Parabrachial nucleus projection to the amygdala in the rat: electrophysiological and anatomical observations. Brain Res Bull 39:115-126.

Johnson AK (2007) The sensory psychobiology of thirst and salt appetite. Med Sci Sports Exerc 39:1388-1400.
Johnson AK, Thunhorst RL (1997) The neuroendocrinology of thirst and salt appetite: visceral sensory signals and mechanisms of central integration. Front Neuroendocrinol 18:292-353.

Johnson AK, Thunhorst RL (2007) The neuroendocrinology, neurochemistry and molecular biology of thirst and salt appetite. In: Lajtha A, Blaustein JD, editors. In Handbook of Neurochemistry and Molecular Neurobiology. 3rd. New York: Springer. p. 641-687.

Koneru B, Bathina CS, Cherry BH, Mifflin SW (2014) Mineralocorticoid receptor in the NTS stimulates saline intake during fourth ventricular infusions of aldosterone. Am J Physiol Regul Integr Comp Physiol 306:R61-R66.

Lanca AJ, van der Kooy D (1985) A serotonin-containing pathway from the area postrema to the parabrachial nucleus in the rat. Neuroscience 14:1117-1126.

Margatho LO, Giusti-Paiva A, Menani JV, Elias LL, Vivas LM, Antunes-Rodrigues J (2007) Serotonergic mechanisms of the lateral parabrachial nucleus in renal and hormonal responses to isotonic blood volume expansion. Am J Physiol Regul Integr Comp Physiol 292:R1190-R1197.

Menani JV, Barbosa SP, De Luca Jr LA, De Gobbi JI, Johnson AK (2002) Serotonergic mechanisms of the lateral parabrachial nucleus and cholinergic-induced sodium appetite. Am J Physiol Regul Integr Comp Physiol 282:R837-R841.

Menani JV, De Luca Jr LA, Johnson AK (1998) Lateral parabrachial nucleus serotonergic mechanisms and salt appetite induced by sodium depletion. Am J Physiol 274:R555-R560.

Menani JV, De Luca Jr LA, Thunhorst RL, Johnson AK (2000) Hindbrain serotonin and the rapid induction of sodium appetite. Am J Physiol Regul Integr Comp Physiol 279:R126-R131.

Menani JV, Johnson AK (1998) Cholecystokinin actions in the parabrachial nucleus: effects on thirst and salt appetite. Am J Physiol 275:R1431-R1437.

Menani JV, Thunhorst RL, Johnson AK (1996) Lateral parabrachial nucleus and serotonergic mechanisms in the control of salt appetite in rats. Am J Physiol 270:R162-R168.

Menani JV, Vieira AA, Colombari DSA, De Paula PM, Colombari E, De Luca LA, Jr. (2014) Preoptic-Periventricular Integrative Mechanisms Involved in Behavior, Fluid-Electrolyte Balance, and Pressor Responses.

Nitabach MN, Schulkin J, Epstein AN (1989) The medial amygdala is part of a mineralocorticoid-sensitive circuit controlling $\mathrm{NaCl}$ intake in the rat. Behav Brain Res 35:127-134.

Sakai RR, McEwen BS, Fluharty SJ, Ma LY (2000) The amygdala: site of genomic and nongenomic arousal of aldosterone-induced sodium intake. Kidney Int 57:1337-1345.

Shade RE, Blair-West JR, Carey KD, Madden LJ, Weisinger RS, Denton DA (2002) Synergy between angiotensin and aldosterone in evoking sodium appetite in baboons. Am J Physiol Regul Integr Comp Physiol 283:R1070-R1078.

Vinson GP, Coghlan JP (2010) Expanding view of aldosterone action, with an emphasis on rapid action. Clin Exp Pharmacol Physiol 37:410-416.

Wendler A, Albrecht C, Wehling M (2012) Nongenomic actions of aldosterone and progesterone revisited. Steroids 77:1002-1006.

Zardetto-Smith AM, Beltz TG, Johnson AK (1994) Role of the central nucleus of the amygdala and bed nucleus of the stria terminalis in experimentally-induced salt appetite. Brain Res 645:123-134. 